\title{
Vowel Raising in Nkpor Dialect: A Pattern of Sound Change
}

\author{
Evelyn Ezinwanne Mbah and Chukwuma Onyebuchi Okeke (Nsukka, Nigeria)
}

\begin{abstract}
This paper explores a pattern of phonological change known as vowel raising in the Nkpor dialect of the Igbo language. Using a corpus of conversational Nkpor speech collected from the respondents through tape-recording, we presented data from an authority analysis of the vowels and auditory data of vowel raising. The data support three main claims. First, the voiced palatal nasal $/ \mathrm{n} /$ is elided. It claims that in a word consisting of two root verbs, the initial verb root contains any consonant and any vowel, and the second verb root contains the voiced palatal nasal /n/ and a mid front vowel /e/, then, the voiced palatal nasal is elided. Second, after the elision, the mid vowel /e/ of the second verb is raised to a high front vowel /i/ or /I/, agreeing with the vowel harmony rule. Third, Nkpor dialect goes beyond the raising of only vowels of the second verb. It further raises vowels of the first verb which are not high. The much more rapid loss of the voiced palatal nasal $/ \mathrm{n} /$ and the consequent raising of the vowels are plausibly attributed to rapid speech, especially in construction and some sociolinguistic factors.
\end{abstract}

\section{$1 \quad$ Introduction}

Vowel raising, according to Podile (2002: 65) is a phonological process where "The tongue height is raised to a higher vowel position in an attempt to be ready for the articulation of the succeeding high vowel." Nkpor dialect, as well as most dialects of the Idemili-North LGA, exhibits the feature of vowel raising. Hagiwara (2005) points to the fact that every language has dialect-forms of the language, characteristic of particular social groups. Some of the most important and distinctive aspects of Igbo dialects (or accents) have to do with the pronunciation of vowel sounds. For instance, in some dialects of Igbo, áká is pronounced with different vowel sounds, and in others, they sound the same. Igbo vowels, according to Laver (1994), have previously been described mostly by careful listening. However, it can be very difficult even for trained experts to simply hear very subtle differences in sound, and even harder to describe these subtleties in ways that can be meaningfully compared. But the above stated point is not within the scope of this paper.

This paper is an exploration of the social factors responsible for a peculiar phonological phenomenon in Nkpor dialect of Igbo known as vowel raising, which involves the deletion of the voiced palatal nasal $/ \mathrm{n} /$, and the raising of the mid vowel /e/ to $/ \mathrm{i} / \mathrm{or} / \mathrm{I} /$ in obedience to the vowel harmony rule. Based on various studies by scholars (Tomás 1948; Holmquist 2001, 2003, 2005) and one of the writer's observation of the Nkpor dialect as a native speaker of the dialect, the writers show evidence of this phonological change. The writers take the issue of phonological change to be particularly germane in view of the evidence that the phonological 
consequences of language contact are often visible; primarily in the vowel system of dialect/languages (see Labov 2010, Watt/Milroy 1999).

\section{About the Igbo Language and Nkpor Town}

The word Igbo refers to the people as well as their language. It is the dominant language in the South-eastern part of Nigeria and it is taught and studied in schools at all levels of education in the country. In the classification of world languages, Igbo belongs to the New Benue Congo language family. As a tone language, Igbo has three phonemic tones, high ('), downstep (-) and low (.). In this paper, only the high and the low tones manifested and as such were the ones marked.

Nkpor is a town located at about six kilometers East of Onitsha, with Ogidi to the North, Obosi to the South-East and Umuoji to the East. The town is at the South-western part of Idemili North Local Government Area of Anambra State of Nigeria. From the most recent population statistics projected in 2006 , its population is about 47,920 . There is a valley which divides the town into two regions resulting in Nkpor-Uno and Nkpor-Agu. This valley is one of the tributaries of the River Niger.

Linguistically, the Nkpor dialect is one of the Eastern Igbo dialect clusters of the Igbo language according to Nwaozuzu's (2008) classification of the Igbo dialects. Formally, they are two major dialects in existence in the town - Nkpor dialect and standard Igbo; but in Nkpor-Agu region of Nkpor, we have the Otu Onitsha dialect according to Ikekeonwu's (1986) study. Grammatically, early forms of the Nkpor dialect had much in common with Standard Igbo, but present Nkpor dialect according to Okeke (2006) appears, after centuries of geographical proximity, to have absorbed some grammatical influences from neighbouring dialects like Ogidi, Onitsha, and Obosi. This notwithstanding, Nkpor dialect is still distinct and peculiar to its speakers.

\section{Purpose of the Study and Research Questions}

One would expect a town like Nkpor, which is a few kilometres from the commercial city of Onitsha to have linguistic homogeneity, but on the contrary, it has more linguistic diversity than one might expect. It is very common to hear people from Nkpor-Agu region cajoling their brothers from Nkpor-Uno on the way they speak; this being that they raise vowels thereby exhibiting some striking phonological differences in their speech. Also, in association, some sound segments are elided and some vowels raised by inhabitants of NkporUno. According to Ikekeonwu's (1986) investigation of the Enu Onitsha dialect, Nkpor dialect is a homogenous dialect. This notwithstanding, the Nkpor dialect exhibits striking linguistic diversities in relation to phonological changes. It is the interest of the researchers to explore this phonological change of vowel raising and elision in order to find out the structural form(s) and nature of vowel raising in the dialect and more importantly, to also find out the sociolinguistic factors responsible for it. In this paper therefore, answers are provided for the following research questions:

a) How are sound segments affected in associative construction in Nkpor dialect?

b) What are the sociolinguistic factors responsible for the sound changes in Nkpor? 


\section{Theoretical and Empirical Studies}

In this section of the paper, vowel raising is discussed in various world languages that share the same phonological pattern and process with vowel raising in Nkpor. But the Nkpor dialect has another phonological process in her vowel raising which is absent in other languages. This latter point is discussed in the sixth chapter of the paper.

Vowel raising, according to Chambers (1973), started from and is usually associated to the Great Vowel Shift in English in the $15^{\text {th }}$ and $16^{\text {th }}$ centuries. The Great Vowel Shift according to him refers to the rearrangement of the entire English vowel system from middle to modern English. Prior to the shift, words like five and house were pronounced [fiv] and [hu:s], with high vowels. The Great Vowel Shift was responsible for lowering their low vowel pronunciation. Thus, we have [fayv] and [haws]. Furthermore, from Chamber's investigation, it is believed that the diphthong-raising pattern is inherited from certain Middle English dialects in which the lowering of [i:] and [u:] stopped at the mid-vowel height in some words.

Also, as we have previously stated in the introduction, vowel raising, according to Podile (2002: 65) is a phonological process where "The tongue height is raised to a higher vowel position in an attempt to be ready for the articulation of the succeeding high vowel." In the 9vowel Sotho-Tswana languages, according to Dichabe (1997), a much less common process also occurs, where the near-close vowels become raised to a position slightly lower than the close vowels, close to the English beat and boot than the very high Sesotho vowels $/ \mathrm{i} / \mathrm{and} / \mathrm{u} /$ ) with ATR, or alternatively with both [+ATR] and [+RTR]. The above definitions of vowel raising/tensing are in consonance with Dailey-O'Cain's (1997) definition of vowel raising or tensing as the process in which mid or low lax vowels are realized at a higher and tenser placement. Vowel raising is of different types depending on the language under investigation.

\subsection{Mid Vowel Raising}

Doke and Mofokeng (1974) define mid vowel raising as a process where / $/$ / becomes /e/ and $/ \mathrm{o} /$ becomes /o/ under the influence of close vowels or consonants that contain hidden close vowels. Furthermore, Doke and Mofokeng (1974) say that the changes are usually recursive to varying depths within the word, though, being a left spreading rule, it is often bounded by the difficulty of foreseeing the raising syllable.

Mid vowel raising, according to Dichabe (1997), is not only present in Sesotho, but also in other languages like English, Makonde, Vulgar Latin, etc. It is common knowledge that all raising of the long mid-front vowel [e:] to [i:], as in green, meat, tree, etc., is part of a sequence of changes known as the Great Vowel Shift. According to Hagiwara (2005) in his classic studies of the English phonology, e- and o- raising as well as the remaining two changes (a-raising, i-/u- diphthongisation) took place in the $15^{\text {th }}$ century. However, from the very beginning, such dating has been contested by historical linguists who adduce instances of spelling indicating a raised pronunciation of the vowel.

Dichabe (1997) points out that in vulgar Latin under the influence of a nearby [j] - which has a very high tongue position, the vowels $[a, \varepsilon, o, i, u]$ were in many cases raised in stressed syllables to [a, e, o, i, u] respectively. These series of sound changes can be regarded as an instance of metaphony, a process that leads to the approximation of one vowel's quality to that 
of another. The effect of [j] across the vowel system was uneven, in that more vowels are affected in some phonetic contexts than in others. Presumably, according to Dichabe, this is due to the fact that [j] itself survived longer in some contexts than in others and so had varying lengths of time to exercise an effect on a nearby vowel. Historians of the Spanish language, according to Dichabe (1997), usually identify different types of [j], depending on the associated context, what subsequently happened to the semivowel and the number of vowels affected by it.

Vowel raising is also present in the Canadian English. Canadian raising was first brought to the attention of linguists by Joss (1942). One of the most salient characteristics of Canadian English from Hagiwara (2005) investigation is the pattern that linguistics calls Canadian Raising. Hagiwara (2005) explains that in the general discussion of diphthongs, English has three phonemic diphthongs. Two of these have low vowels as their nucleus [ar] as in ride and [av] as in loud. In Canadian English, both of these diphthongs have variants whose occurrence is obligatory under certain phonological conditions. Before a voiceless consonant, the diphthong $[\Lambda \mathrm{y}]$ replaces $[\mathrm{ar}]$, and $[\Lambda \mathrm{w}]$ replaces $[\mathrm{a} \sigma]$. These variants are called raised or centralized diphthongs because their nucleus is no longer a low vowel.

Despite its name, Chambers (1973: 34) avers that the phenomenon of vowel rising is not restricted to Canada; "... it is quite common in New England and Minnesota, Upper Michigan, and other Upper Midwestern States, and has been reported in the traditional accent of Martha's vineyard." He goes further to say that true Canadian raising affects both /av/ and /aI/ diphthongs, but a related phenomenon of much wider distribution throughout the United States affects only/aI/ diphthong. So, whereas the general American pronunciation of rider and writer are identical [rairə], those, whose dialects include either the full or restricted Canadian raising will pronounce them as [rairə] and [r $\Lambda$ Itə] respectively. This raising of /ai/ can be found in the Pacific Northwest, New England, and Philadelphia and probably in many other parts of the country as well, as it appears to be spreading. Note also that this phenomenon preserves the recoverability of the phoneme / $t /$ in writer despite the North American English process of flapping, which merges /t/ and /d/ into [ $\mathrm{r}$ ] before unstressed vowels.

\subsection{Final Vowel Raising}

According to Clements and Rialland (2005), in Makonde dialects of Mozambique final vowels are raised. The final mid vowels [e] and [o] of certain non-verbal forms are raised to $[i]$ and $[\mathrm{u}]$ respectively. Example:

- muúti< muútwe 'head'

- Chituudi < Chituundwe 'anger'

- Lutáanu < Lutáaano 'story'

- Ing'oówu < ing'oówo 'banana'

- $\quad-m u<-m o$ 'a(n)', 'one'

- $\quad-n u<-n o$ 'this' 
Furthermore, with some forms according to Clements and Rialland's (2005) investigation, the raising is found in non-final position. Example:

- $\quad-u m i<-o m i$ 'healthy', 'strong'

- - ahi-ohe $<$-ohe-ohe 'every'

In the work of (2006), in central Veneto dialect, he discovers that a post-tonic high vowel causes /e, o/ to raise to $[\mathrm{i}, \mathrm{u}]$ in a stressed syllable. Again, that when stress is antepenultimate and the high trigger vowel is final, a mid vowel in the penult can undergo raising too. From

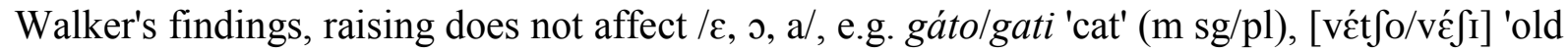
man' (m sg/pl). Of / $\varepsilon, \rho, a /$, only /a/ occurs in an unstressed syllable, and it blocks harmony between a final vowel and the antepenult. Furthermore, Walker avers that raising in an unstressed mid penult vowel only occurs when a stressed vowel undergoes raising. In other words, the raising harmony is non-myopic. Example:

- (a) kalsélo kalsíli 'soak' (m sg/pl)

- (b) móvo múvi 'move' $(1 \mathrm{sg} / 2 \mathrm{sg})$

- (c) órdeno úrdini 'order' $(1 \mathrm{sg} / 2 \mathrm{sg})$

- (d) la(v)órava la(v)óravi 'worked, was working' (1 sg/2sg impf.)

- (e) ángolo ángoli 'angle' (m sg/pl)

In Cameroon, Ngessimo and Chie (2006) investigate the phonological change of vowel raising in Babanki, a grass field Bantu language of north-western Cameroon. They discover the manifestation of vowel raising, where the back vowels $/ \mathrm{a} /$ and $/ \mathrm{o} /$ alternate with $/ \mathrm{o} / \mathrm{and} / \mathrm{u} /$ respectively in associative and possessive constructions, just in case they are part of the sequence [Vy] (where V stands for vowel). Example: Nouns

- mìàg 'walking stick', mbòghóm 'my walking stick'

- ntay 'rope', ǹtòwu 'your rope'

The above instances of vowel raising across world languages show that vowel raising manifests in different forms and conditions in various languages. Also, the manifestation of vowel raising is restricted to certain contexts and conditions depending on the language under investigation.

\section{$5 \quad$ Methodology}

One major objective of the study is to investigate the social factors that affect vowel raising in Nkpor dialect. In doing that, the auditory nature and form of vowel raising in the dialect was also investigated. A total number of 70 respondents were interviewed in Nkpor. Using the clustered purposive random sampling method, 40 males and 30 females were selected. The age groups and the sample size of the study are as follows: children (5-12 years old) 5 males, 2 females; teenagers (13-19 years), 6 males, 2 females; young adults (20-35) 5 males, 11 females; adults (36-55) 9 males, 5 females; and elders (56 and above) 10 males, 15 females. Children, adolescents, young adults, adults and elders were included to observe the pattern of vowel raising across generations. The linguistic variables (i.e. the $\mathrm{CV}+$ nye, see e.g. 1 below) were correlated with the subject's social factors. Three extra linguistic factors were examined 
in this study: age, gender, and mobility. The last factor (mobility) is an added index to the socioeconomic status in Nkpor because in recent years, mobility has made the contact and interaction of people easier in the town. By this we mean that the social network relationship of Nkpor people with their neighbours has contributed to the high degree of human interaction and mixture of different dialects of the Igbo language with Nkpor dialect. The interview included casual conversation of approximately 30 minutes to an hour on topics that were familiar to the respondents. All interviews were transcribed using phonetic symbols. The data were analyzed using tables, frequencies and percentages.

\section{Data Presentation, Interpretation and Analysis}

In some Igbo dialects, especially the Igbo dialects of Idemili-North and South L.G.A's, vowel raising occurs, which must involve the phonological process of elision. Various studies on vowel raising and elision and the relationship between them have been carried out by scholars like Hualde (1991), Kenstowez and Kisseberth (1996) as classic examples of rule ordering in synchronic derivational phonology; and/or in processes of phonological change (Hualde 1998; Hualde/Gaminde 1998; Trask 1996). But in the language under study, they are restricted to contexts where a second verb root that bears the voiced velar nasal exists. Examples:

\section{(1) Slow speech}

a) $/$ mà + né/ > measure + give

b) $/$ bà + né/ > soak + give

c) $/$ kù + nél > carry + give

d) /dó + né/ place + give

e) /fù + né/ > blow + give

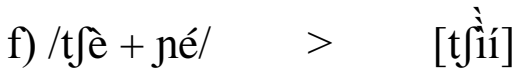
think + give

g) /sì + né/ aim + give

h) $/$ kè + né/ > share + give

i) $/ \mathrm{t} i+$ né/ > crack + give
Rapid speech

$$
\text { [miín }
$$

[kùí]

[dùìi]

[füíi]

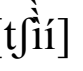

\section{Gloss}

measure and give to

soak in water

use cup/container to give water

place something inside something

blow light/fire into

put a container to get water

put something on fire

give one a share

put something into $\mathrm{rub}+$ give 

k) /lù + né/ >
point + give
[lựí]
insert into
1) /fò + né/ >
insert + give
insert forcefully into
m) /sò + né/ >
[suí]
be part of
follow + give
n) $/$ mì + nél
suck + give
o) $/$ nò + né/ >
stay + give
p) /nè + né/
look + give
[nií]
look into
q) /kò + né/
hang + give
[kòi $]$
hang on
r) /bù + né/ >
[bùi ]
carry/give to
big + give
s) $/$ kpì + né/ >
miserly + give
[kpiín
secretly put into
t) $/$ kà + nél $>\quad$ [kai $] \quad$ incise into
waive + give

In examples (1) above, different manifestations of phonological change occur. They involve elision and vowel raising. The voiced palatal nasal $[n]$ is elided following the formalized phonological rule below:

$$
\left.\begin{array}{c}
\mathbf{C} \\
+ \text { nas } \\
\text {-ant } \\
+ \text { cor } \\
+ \text { voi } \\
+ \text { high }
\end{array}\right) \longrightarrow \varnothing / \# \text { CV\# }-\left(\begin{array}{c}
\mathbf{V} \\
+ \text { syll } \\
+ \text { ATR } \\
- \text {-high } \\
- \text { low } \\
- \text { back } \\
- \text {-round }
\end{array}\right)
$$

In a word consisting of two root verbs, the first verb contains any consonant sound and any vowel sound, and the second root verb contains a voiced palatal nasal $[\mathrm{n}]$ and a mid-front 
vowel /e/, the voiced palatal nasal [n] is elided. After the elision, vowels in (1) which are not high are raised. Initially, the mid-front vowel [e] of the second root verb is raised to the highfront vowel [I] or [i] in agreement with the rule of vowel harmony. Generally, phonological rules are ordered. That is why the voiced palatal nasal is first elided, followed by the raising of /e/ in the second verb root, which follows the vowel harmony rule as in examples (2) below:

$$
\begin{aligned}
& \text { (2) } / \text { kù }+ \text { né/ } \quad \rightarrow \quad \text { [kùí] } \\
& / \text { kà }+ \text { nél } \quad \rightarrow \quad[\text { kài }] \\
& / \mathrm{t} \int \mathrm{i}+\text { nél } \quad \rightarrow \quad\left[\mathrm{t} \int \hat{i n i} \mathrm{i}\right] \\
& \text { /sì }+ \text { nél } \quad \rightarrow \quad \text { [sií] } \\
& / \text { nè }+ \text { nél } \rightarrow \quad \text { [nèí] } \\
& \text { /kò + né/ } \quad \rightarrow \quad[\text { kòi }] \\
& \text { /dò }+ \text { nél } \quad \rightarrow \quad \text { [dọ̀in] } \\
& \text { /fừ + né/ } \quad \rightarrow \quad \text { [fùíi }]
\end{aligned}
$$

Examples (2) above can be formalized thus:

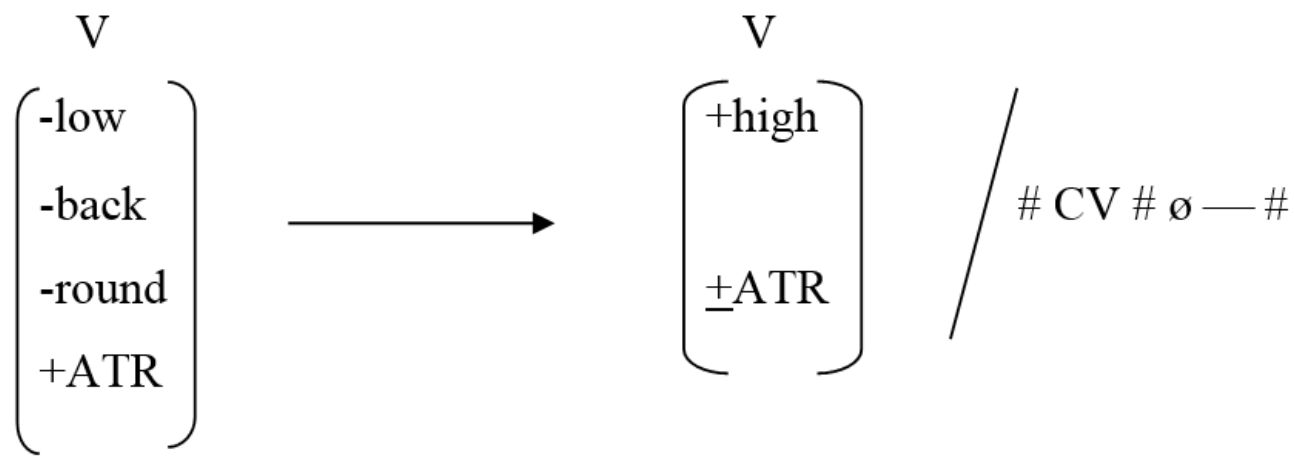

The phonological rule states that the mid front vowel /e/ changes to a high-front vowel [I] or [i] (depending on the vowel harmony set of the preceding vowel) at final position after the elision of the voiced palatal nasal $/ \mathrm{n} /$ has taken place. This happens if the preceding verb contains any consonant and any vowel.

Nkpor dialect, like most dialects of Idemili-North and South (example Oba dialect, see Emekekwue 1998), unlike the majority of dialects of Igbo and other languages like Canadian English, Japanese, etc. (as discussed earlier) does not stop at the raising of only vowels of the second verb. It further raises the vowels of the first verb root which are not high, especially in very rapid speech. Based on this, we have the following phonological changes:
(3) (a) /bàí/

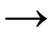
[bii]
(b) /sòi/

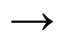
[sùí]
(c) /t teéí/
$\rightarrow$
[tfií]
(d) fòí
$\rightarrow$
[fưín] 
The following can be deduced from vowel raising in (3). See example (4) below:
(4) (a) $/ a /$
$\rightarrow$
[i]
(b) $/ \mathrm{o} /$
$\rightarrow$
[u]
(c) $/ \mathrm{e} /$
$\rightarrow$
[i]
(d) $/ \mathrm{s} /$
$\rightarrow$
$[\mathrm{u}]$

Examples (4) above can be formalized thus:
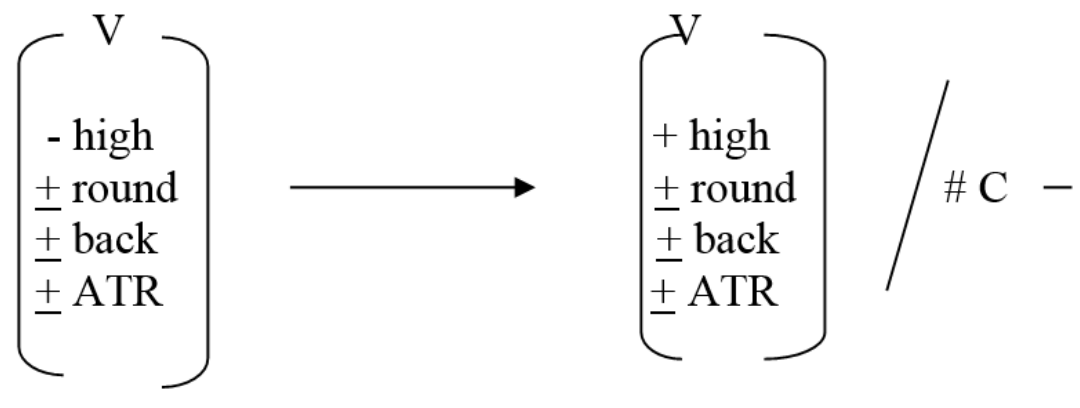

The above rule shows that a non-high vowel becomes high and copies all other vowel qualities of the changing vowel. From the above deduction of vowel raising, /a/ was raised to [i] and $/ \mathrm{J} /$ was raised to $\left[\mathrm{u}_{n}\right.$. Also, /o/ was raised to[u] and /e/ was raised to [i] in order to agree with their harmony sets of + ATR and - ATR. The rule for the change states that any vowel which is not high is raised to a high vowel in its vowel harmony set when the vowel to be raised is between any consonant and any vowel after the elision of $/ \mathrm{n} /$.

\subsection{Overall Results}

From a total of 2000 tokens, 1600 were raised and 400 were not raised. Tables 1 and 2 show the frequencies and percentages of raised and non-raised tokens of each group, from NkporAgu or Nkpor-uno regions of Nkpor town, while Table 3 summaries the two regions.

\begin{tabular}{|c|c|c|c|c|c|}
\hline Age Groups & Raised & \% Raised & Not Raised & \% Not Raised & Total \\
\hline Young Adults & 60 & 3.75 & 75 & 18.75 & 135 \\
\hline Adults & 170 & 10.62 & 160 & 40 & 330 \\
\hline Elders & 225 & 14.06 & 12 & 3 & 237 \\
\hline Total & $\mathbf{4 5 5}$ & & $\mathbf{2 4 7}$ & & $\mathbf{7 0 2}$ \\
\hline
\end{tabular}

Table 1: Vowel Raising Results in Nkpor-Agu Region

\begin{tabular}{|c|c|c|c|c|c|}
\hline Age Groups & Raised & \% Raised & Not Raised & \% Not Raised & Total \\
\hline Young Adults & 280 & 17.51 & 42 & 10.5 & 322 \\
\hline Adults & 365 & 22.81 & 104 & 26 & 469 \\
\hline Elders & 500 & 31.25 & 7 & 1.75 & 507 \\
\hline Total & $\mathbf{1 1 4 5}$ & & $\mathbf{1 5 3}$ & & $\mathbf{1 2 9 8}$ \\
\hline
\end{tabular}

Table 2: Vowel Raising Results in Nkpor-Uno Region 


\begin{tabular}{|c|c|c|c|c|c|}
\hline Age Groups & Raised & \% Raised & Not Raised & \% Not Raised & Total \\
\hline Young Adults & 340 & 21.26 & 117 & 29.25 & 457 \\
\hline Adults & 535 & 33.43 & 264 & 66.0 & 799 \\
\hline Elders & 725 & 45.31 & 19 & 4.75 & 744 \\
\hline Total & $\mathbf{1 6 0 0}$ & & $\mathbf{4 0 0}$ & & $\mathbf{2 0 0 0}$ \\
\hline
\end{tabular}

Table 3: Summary of Vowel Raising Results in the two Regions

From Table 3 above, out of the 2000 tokens used, 1600 token were raised (see formalized rules 1, 2 and 3 above), depending on how rapid the utterance is; and 400 tokens were not raised. The highest percentages of unraised tokens are from the Nkpor-Agu region of Nkpor while the highest percentage of raised tokens came from Nkpor-Uno region, (see Tables 1 and 2 above). Again, the raised tokens are more from the elders because they have highest percentage of $45.31 \%$.

\subsection{Social Factors and Vowel Raising in Nkpor}

Social factors in this context are the extra-linguistic variables like gender, age, etc, that influence the linguistic variables.

\section{Age}

A Chi-square test indicates no significant difference of vowel raising frequencies between Young Adults and Adults in Nkpor. However, there is a Chi-square value of 5.41, $\mathrm{P}<0.025$ between young Adults and Elders and a Chi-square of 6.22, $\mathrm{P}<0.0025$ between Adults and Elders indicating that there are significant differences between the ages of 20 to 55 and Elders.

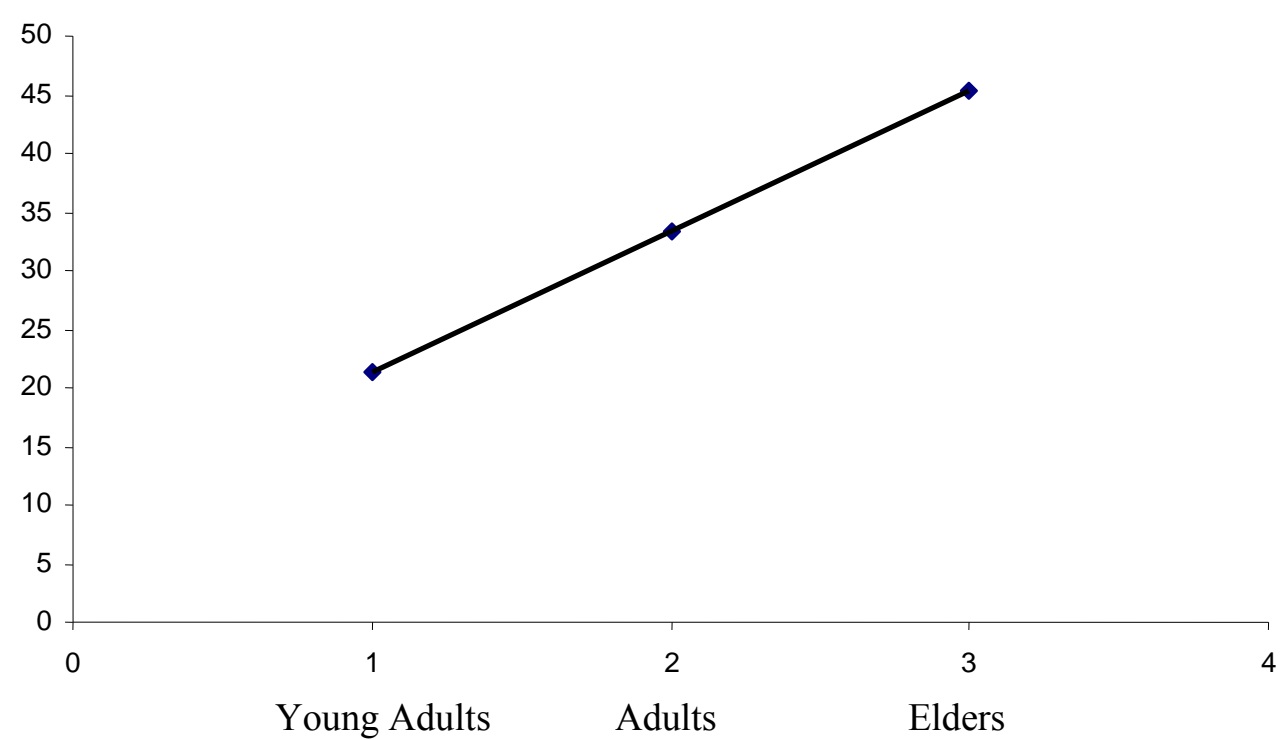

Figure 1: A Graph Showing the Percentages of Vowel Raising Across the Discussed Groups (using Table 3)

This shows that vowel raising is more among the Elders in Nkpor-uno speech community. 


\section{Mobility}

Mobility in this context refers to the social network relationship of the people. Nkpor is divided into two regions via Nkpor-Agu and Nkpor-Uno. People from Nkpor-Agu region interact more with non-natives and the population is heterogeneous because of the commercial city of Onitsha (cf. Okeke 2006). They travel out and tend to lose the features while the Nkpor-Uno people with less mobility and urbanization had more instances of vowel raising. Respondents who were born and raised in Nkpor-Uno and rarely moved out (i.e. they have very low social network relationship with outsiders) of the area received the category of Never-out, and those of Nkpor-Agu who moved out (i.e. they have very high social network relationship) for education or business are labeled Out. Table 4 shows the proportion of vowel raising by mobility.

\begin{tabular}{|c|c|c|c|c|}
\hline Age Groups & Mobility & Raised Tokens & Non-Raised & Total \\
\hline Young Adults & Out & 200 & 64 & 264 \\
\hline & $\%$ & 75.76 & 24.24 & \\
\hline & Never Out & 185 & 54 & 239 \\
\hline & $\%$ & 77.40 & 22.60 & \\
\hline Adults & Out & 230 & 87 & 317 \\
\hline & $\%$ & 72.56 & 27.44 & 642 \\
\hline & Never Out & 550 & 92 & 199 \\
\hline & $\%$ & 85.67 & 14.33 & 44 \\
\hline & Out & 155 & 22.11 & \\
\hline & Never Out & 280 & 59 & 17.40 \\
\hline
\end{tabular}

Table 4: Vowel Raising Frequencies by Mobility.

The degree of difference between vowel raising frequencies among Never Out and Out is highly significant from the above table. The raised tokens are more among the Never Out with 550 tokens raised as against 230 tokens of raised tokens among the respondents that are labeled Out.

Finally, the proportion of vowel raising by gender, age group and mobility was accessed. 


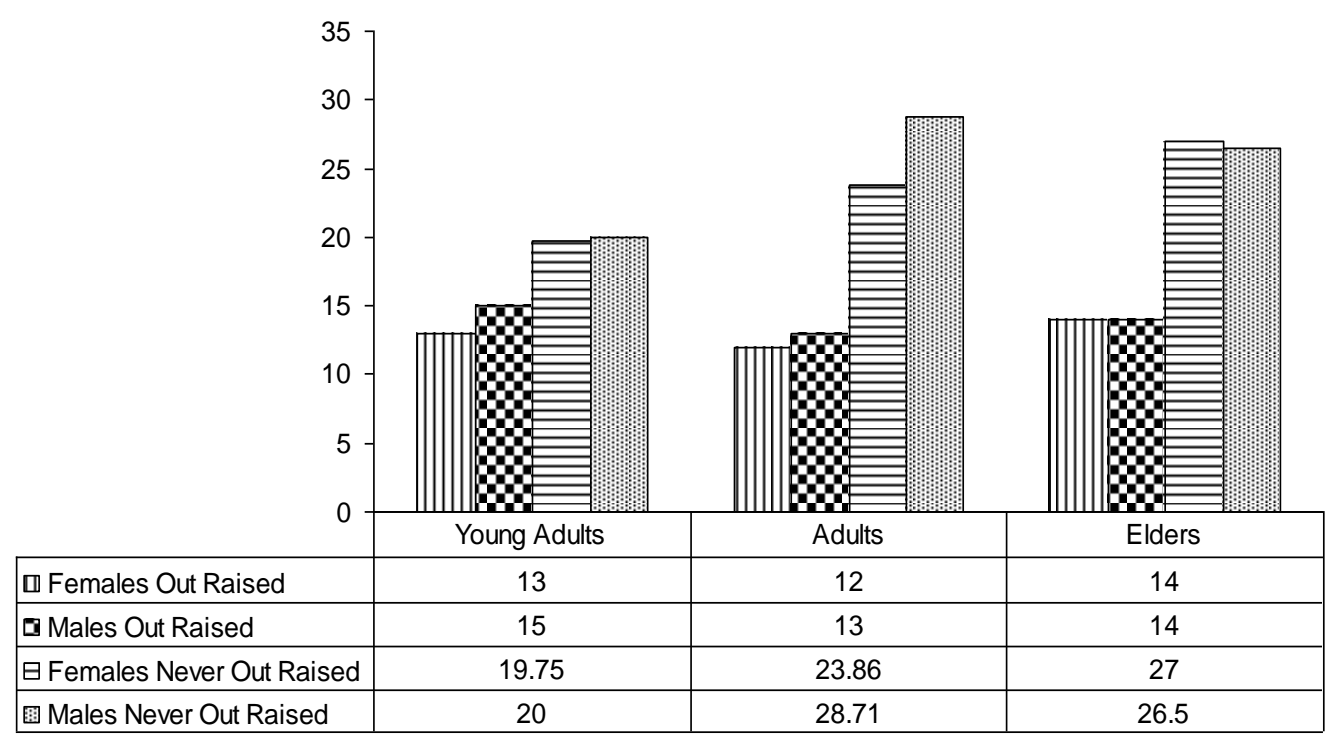

Figure 2: Proportion of Vowel Raising by Gender, Age group and Mobility

People who have never been out of Nkpor-Uno have more vowel raising than those who have been out of the region. Figure 2 indicates that both males and females who stayed local have more vowel raising than those who lived outside the region. Labov (2001) posits that women are mostly responsible for sound changes that are stigmatized. Furthermore, Labov says that women who lived in urban areas understand that vowel raising is a stigmatized feature and this explains their decreased vowel raising frequencies compared to men who have been out. The findings of the paper conform to the findings postulated by Labov as can be seen in Figure 2. Figure 2 also shows that vowel raising increases across generations. Young women in the category of Never Out have an average raising of $19.75 \%$ raised tokens, while elder women in the same category have $26.5 \%$ raised tokens. Thorne (1993: 51) finds out that "where age separation is present, gender separation is more likely to occur."

From the above analysis, we can see that the social interaction resulting from language contact influences the phonological change of vowel raising in the Nkpor dialect of the Igbo language. People of Nkpor-Uno region of Nkpor do not have access to the commercial city of Onitsha, thus, changes are slower as influences from their neighbours are limited. This conforms to Thorne (1993) that to some extent, the differences in pronunciation are part of geographical dispersion of dialects.

\section{$7 \quad$ Summary of the findings and Conclusion}

This paper has analyzed the phenomenon of phonological change known as vowel raising, and the sociolinguistic variables influencing it. Vowel raising is a form of sound change due to vowel interaction which mostly occurs in rapid speech of some Nkpor indigenes, whose social network relationship is very low. In Nkpor-Uno dialect of Nkpor, vowel raising involves elision; and the environment is restricted. It occurs only in compound words made up of two root verbs. The second verb root of the compound word must be the voiced palatal nasal $/ \mathrm{n} /$ and the mid-front vowel /e/; and the first verb root could contain any consonant or any vowel. Because phonological rules are ordered, the voiced palatal nasal $/ \mathrm{n} /$ is first elided. 
Consequently, all the vowels which are not high are raised to high vowels. This is possible on the condition that the vowel of the first word is a low front vowel.

Then, the vowel of the second root verb will change to a high front vowel while if it is a low back vowel, the vowel of the second root will be a high back vowel. This phonological change obeys the vowel harmony rule strictly. The data analysis report in this study suggests that both the mid front vowel raising and voiced palatal nasal elision are being lost in NkporAgu region of Nkpor plausibly as a consequence of contact with the commercial city of Onitsha.

Again, people who move out tend to modify their speech to reduce the instances of vowel raising. Their speech starts to resemble the dialect of the Otu Onitsha (cf. Ikekeonwu 1986; Okeke 2006). Also, Labov (2001: 311) states that "... every change must show a decline among younger speakers to some extent". The above assertion by Labov, to some extent is evident in this research work because most of the younger respondents did not show evidence of vowel raising (see Table 3 ). The data also suggest that there is no significant difference in vowel raising between males and females of the same age group but there is a significant difference across age groups. This is because the phonological process of vowel raising is gradually disappearing among the younger generation. Finally, respondents (elderly) who are never out in Nkpor-Uno showed the highest evidence of vowel raising, while the ones that are out of Nkpor-Uno did not show much evidence of vowel raising in their speech.

\section{References}

Chambers, Jack K. (1973): "Canadian Raising". Canadian Journal of Linguistics 18/2: 113135.

Clements, George N./Rialland, Anne (2005): "Africa as a Phonological Area". In: Bernd, H./Derck, N. (eds.) (2005): Africa as a Linguistic Area. Cambridge: Cambridge University Press.

Dailey-O'Cain, Jennifer (1997): "Canadian Raising in a Midwestern U.S. City". Language Variation and Change 9/1: 107-120.

Dichabe, Betty (1997): Advanced Tongue Root Harmony in Setwana. MA Thesis, University of Ottawa.

Doke, Clement M./Mofokeng, S. M. (1974): Textbook of Southern Sotho Grammar. Cape Town: Longman.

Emekekwue, Evelyn E. (1998): Patterns of Sound Change in Oba. BA Project, University of Nigeria, Nsukka.

Hagiwara, Rob (2005): Visualizing the Canadian English Vowels. A Paper Presented at the Joint ASA/CAA Meeting, Vancouver, BC.

Holmquist, Jonathan C. (2001): "Variación Vocalicá En El Habla Masculine De Castarier, PR". Cuaderno International Estudios Hispanicosy Linguistica 1: 96-103.

Holmquist, Jonathan C. (2003): "Coffee Farmers, Social Integration and Five Phonological Features. Regional Socio-Dialectology in West-Central Puerto Rico". In: Sayahi, L. (ed.) (2003): Selected Proceedings of the Workshop in Spanish Sociolinguistics. New York, Cascadolla Proceedings Project: 70-76.

Holmquist, Jonathan C. (2005): "Social Stratification in Women's Speech in Rural Puerto Rico: A Study of Five Phonological Features". In: Sayahi, Lotfy (ed.) (2005) Selected 
Proceedings of the First Workshop in Spanish Sociolinguistics. Somerville/MA, Cascadolla Proceedings Project: 109-119.

Hualde, Jose I./Gaminde, Inaki (1998): "Vowel Integration in Basque: A Nearly Exhaustive Catalogue". Studies in the Linguistic Science 28/1: 41-77.

Hualde, Jose I. (1991): Basque Phonology. London: Routledge.

Hualde, Jose I. (1998): "Vowel Integration and Related phenomena in Basque and the Nature of Morphophonological knowledge". Cognitive Linguistics 10/1: 33-56.

Ikekeonwu, Clara I. (1986): A Lexico-Phonotactic Study of the Northern Igbo Dialects. PhD Thesis, University of Nigeria, Nsukka.

Kenstowez, Michael/Kisseberth, Charles (1996): Phonology in Generative Grammar. Blackwell: Malden Mass.

Labov, William (2001): "Principles of Linguistic Change". In: Labov, William (ed.) (2001): Social Factors. Oxford: Blackwell.

Labov, William (2010): Principles of Linguistic Change: Cognitive and Cultural Factors. United Kingdom: Wiley-Blackwell.

Laver, John (1994): Principles of Phonetics. Cambridge: Cambridge University Press.

Ngessimo, Mutaka M./Chie, Esther P. (2006): Vowel Raising in Babanki. A Paper Presented at the $25^{\text {th }}$ WALL, at the University of Benin, Cotonou.

Nwaozuzu, Gabriella I. (2008): Dialects of the Igbo Language. Nsukka: University of Nigeria Press.

Okeke, Chukwuma O. (2006): Language Attitude and Language Shift: A Case Study of Nkpor Dialect. Unpublished MA Thesis, University of Nigeria, Nsukka.

Podile, Kholisa (2002): The Dependency Relations within Xhosa Phonological Process. MAThesis, University of South Africa.

Walker, Rachel (2006): Gradualness and Fellswoop Derivation. London: Edward Anorld.

Tomás, Tomás Navarro (1948): El Español En Puerto Rico: Contribuciòn a La Geografia Linguistica Hispanoamericana. Editorial Universitonia, Universidad De Puerto Rico.

Thorne, Barrie (1993): Gender Play: Curls and Boys in School. New Brunswick/N.J: Rutgers University Press.

Trask, Larry (1996): Historical Linguistics. London: Edward Anorld.

Watt, Dom./Milroy, Lesley (1996): "Patterns of Variation and Change in Three Newcastle Vowels: Is This Dialect Levelly?". In: Foulkes, Paul/Docherly, Gerard (eds.) (1996): Urban Voices. London, Edward Anorl: 25-36. 